\title{
THE IMPLEMENTATION OF PORT MANAGEMENT POLICY IN PELINDO III TANJUNG PERAK SURABAYA
}

\author{
Sony Kunila', Budi Rianto², Viv Djanat Prasita ${ }^{3}$, Lunariana Lubis ${ }^{4}$ \\ ${ }^{1}$ Social and Political Science Faculty, Hang Tuah University Surabaya \\ ${ }^{2}$ Social and Political Science Faculty, Hang Tuah University Surabaya \\ ${ }^{3}$ Engineering and Marine Science Faculty, Hang Tuah University Surabaya \\ ${ }^{4}$ Social and Political Science Faculty, Hang Tuah University Surabaya
}

Corresponding email: lunariana.lubis@hangtuah.ac.id

\begin{abstract}
Research on the implementation of the Port Implementation policy at Pelindo III Tanjung Perak Surabaya (Case study of the Implementation of the Minister of Transportation's Regulation Number: PM 146 of 2016 concerning changes to the Minister of Transportation's regulation PM Number 51 of 2015 concerning the Implementation of Seaports) aims to analyze the implementation of Port Operational Policies at Pelindo III Tanjung Perak Surabaya. In addition, to analyze the factors that support and hinder the successful implementation of the Port Management in Pelindo III Tanjung Perak Surabaya. This research uses a qualitative method with a case study approach. Data collection is done through interviews, observations and documentation and then analyzed through data reduction, data presentation and conclusions. The results show that Port Management Policy in Pelindo III has been implemented between Pelindo III, Syahbandar, and other stakeholders, even though there are some inhibiting factors, such as the lack of human resource quality, the complexity of the bureaucracy in handling export and import documents and ship waiting time at port.
\end{abstract}

Keywords: Implementation, Policy, Port

\section{INTRODUCTION}

Sea transportation is the main route to connect the islands of Indonesia and must fulfill the criteria to support industrial activities and other services. It also considered as the league that serves national, regional and international areas. Therefore, the role of the seaport is very strategic and important so that it can dominantly support the sustainability of the national economy.

The current condition of sea transportation implementation can be described based on the conditions of five elements, namely transportation in waters, port, shipping safety and security, maritime environment protection, and human resources that interact and create the effective and efficient operation of sea transportation (Source: Directorate General of Sea Transportation, Ministry of Transportation, 2015). The operation of the seaport is the government's sea activities and business activities that are used for the ships to dock, passenger boarding, loading and unloading goods, such as the terminal, and the ship harbor. The ship harbor is equipped with port facilities.

Tanjung Perak is the second and busiest harbor in Indonesia after Tanjung Priok because the position is between the western and eastern regions of Indonesia (Syarifuddin, Al Musadieq, \& Yulianto, 2016). This position causes the high of ship travel that would enter and exit from Tanjung Perak Port. For this reason, it would exceed the specified capacity. Pelindo III company provides port service facilities and has a key role in ensuring the continuity of the sea transportation (Andhika, 2015). The capacity of the ship's movement as determined as many as 27,000 each year or 13,500 ships that exit and enter the port every year. The number of regular vessels that anchor in Tanjung Perak, are 35 units each, 19 PELNI ships and 16 Roll-on Roll-off ships (RoRo) owned by a private company (Sumber : BPS Kota Surabaya, 2017).

The number and the capacity of ships dock and depart from Tanjung Perak Port can be ascertained, including passenger capacity, for both PELNI and RoRo ships. Likewise, the cargo of goods, animals, and passengers 
should be listed according to the reality on the ship at the time of sailing. The method is a safety and security sub-system that must be considered as a basis and benchmark for decision making in determining shipping eligibility. The eligibility can be seen in terms of facilities, such as ships; infrastructure, such as navigation systems; and human resources in it. According to the Regulation of the Minister of Transportation of the Republic of Indonesia Number: PM 146 Year 2016 concerning Amendment to the Regulation of the Minister of Transportation of the Republic of Indonesia Number 51 Year 2015 concerning the operation of seaports (RI, 2016), particularly Article 6 states that Port Authority conducts the activity commercially, such as in Pelindo III. Tanjung Perak Port has the duty and responsibility not only to provide the area on land and waters but also to maintain navigation aids. Furthermore, it also ensures the security and order at the port, guarantee and maintain environmental sustainability at the port, and set the port master plans. The port has the responsibility to suggest the rates to the Minister of Transportation for the use of water, land, and port facilities and services suitable for the provisions of legislation and regulations. It also must guarantee the continuity of goods and services.

The observations show some problems, such as organizing the merchant ships and fleet, incompatibility of the minimum speed requirements of many ships, lack of adequate infrastructure at the port, electronic ticketing is not fully implemented, and the lack of qualification of seafarers and port employees. The new facilities which aim to support infrastructure and management systems, have not been able to optimize various services and procedures as well as to improve port operations. Therefore, this study tries to analyze the implementation of port management policy in Pelindo III Tanjung Perak Surabaya.

\section{MATERIALS AND METHODS}

\section{Theoretical study}

Carl J. Friedrich (Hasibuan, 2014) states that the government makes the policies to support the development process and solve the problems that exist in the society. In line with this, the policy is a direction of action suggested by a person, group or government in a particular environment concerning the existence of certain obstacles to achieve a goal or to realize a certain objective.

Van Meter and Van Horn have developed the policy implementation process model that the change, control, and conformity in every action are important concepts in implementation procedures. Both of them have developed a typology policy according to the number of changes that will result and the scope of agreement on the objectives of various parties involved in the implementation process (Akib, 2010).

Van Meter and Van Horn consider implementation is an action by an individual, official, group of government or private foundation which is guided to achieve the objectives outlined in a particular decision. These foundations implement the government's work that has an impact on the citizen (Mandala, Setyadiharja, Jefri, Renaldi, \& Mulyani, 2016). If a policy is inaccurate or not able to reduce the problem of the policy target, so that it may fail even if it is implemented well. Moreover, a brilliant policy might also fail if the policy is not conducted properly by the implementer.

Van Meter and Van Horn initiate the theory of implementation by presenting six variables, namely (1) standard and policy objectives; (2) resources; (3) communication; (4) inter-organization and confirmation activities; (5) characteristics of the implementing agent; (6) social, economic, and political conditions, as well as the character of the implementer (Solichin, 2015).

\section{Research methodology}

The study uses a qualitative method that is conducted in a real condition to investigate and understand what, why, and how phenomena have happened (Chariri, 2009). This is a case study approach that explores a problem in detail, have in-depth data retrieval, and include various sources of information (Rahmat, 2009).

The data collected in this qualitative study has three phases (Hasibuan, 2014), namely (1) observation means that the data collection is done through an observation at Pelindo III Tanjung Perak Surabaya. (2) Interview which is conducted to several informants, such as human resources and general manager and the employees of Pelindo III company. (3) Documentation is done by categorizing and clarifying written material and pictures in Pelindo III company which are considered as the complement of observation and interview

The data is collected, processed and analyzed simultaneously. The data analysis technique uses an interactive analysis model suggested by Miles and Huberman, 1984 (Syahruddin, 2010), namely the collection, presentation, reduction, and conclusion. 


\section{RESULT AND DISCUSSION}

Pelindo III is a state-owned enterprise engaged in the transportation sector that has the duty, authority and responsibility to manage public ports in seven provinces in Indonesia, namely East Java, Central Java, Bali, South Kalimantan, Central Kalimantan, West, and East Nusa Tenggara. Pelindo III company is responsible for the shipping safety based on the legislation of public port implementation.

Van Meter and Van Horn suggest six variables for implementation, they are:

1. Standard and Policy Target

Pelindo III company has vision, mission, culture, and strategy to conduct services in the port sector. The company provides the dock for mooring, refueling and refilling clean water. It also gives facilities for passengers and vehicles, loading and unloading goods or containers, storeroom and stockpiling, loading and unloading equipment, container terminal services, liquid bulk, dry bulk, Roll-on Roll-off ships (RoRo), goods distribution and consolidation center, and ship delay services.

2. Resources

Pelindo III company in Tanjung Perak Surabaya has a high commitment to manage human resources. It provides fair and equal treatment for all employees. The treatments mean that providing equal opportunities for each employee to develop themselves and show the best potential for the company. The regulations of Pelindo III company is stated in Director' Regulations which are well-archived. Each activity in the company has been regulated, regarding the provision of salary, allowance, annual leave, mutation, knowledge management activities, family activities, and employee gathering. The placement of employees is well managed based on their respective expertise and the placement choice in the recruitment. The placement of employees adjusts to the expertise based on the human resources specifications, such as degree, major, achievement, and other abilities. Furthermore, training is also given to the employees to make them understand in providing effective and efficient services.

The measurement of company performance in the state-owned enterprise is based on Ministerial Decree Number KEP100 / MBU / 2002, in which the company receives A category and healthy predicate.

Pelindo III company has implemented various innovations that can improve customer services. The innovations are the improvement of terminal cluster services (passengers, cargo, public services), the platform application system (services via website), modern passenger terminal (Gapura Surya Nusantara), the application of SIMPANDU (Integrated Management System), increasing the scout officers and container crane in Nilam terminal.

3. Communication

The established communication is among the authority as the regulator and Pelindo III company as the operator. Good communication can be seen from the good coordination between related organizations. Each of them performs Syahbandar roles in the management of Tanjung Perak port with the duty of carrying out supervision and law enforcement in shipping safety and security, as well as the government activity coordination in the port. Good communication continues to be pursued in the management of the seaport in Tanjung Perak Surabaya. The communication among the related organizations for the implementation of port management continues to be maintained.

4. Inter-organization and inaugural activity

Providing services to the users or customers should be suitable for the rules and service procedures of Pelindo III company. Socialization and publication related to Standard Operational Procedure are established, such as holding meetings between Pelindo III company and the service users who discuss the service standards. Furthermore, they also post the procedure of service on the banners, pamphlets and internet media such as Facebook, Instagram, YouTube, and the company website.

5. The characteristics of the implementer.

Pelindo III company has made a handbook and XBanner related to the company culture in every room and office which aims to make the employees always remember and implement the culture and values to their works and services for the customers. Furthermore, the port operational structure is under the control of the central government, which is in Tanjung Perak Port. The authority is as the port regulator and Pelindo III company serves as the port operator. The implementation of the seaport policy is supported by the organizational structure such as Pelindo III company, Syahbandar Tanjung Perak Surabaya, KPLP Tanjung Perak Port, Directorate General of Sea Transportation, and Directorate of Guard Unity in the Sea and Coast.

6. Social, economic and political conditions

Tanjung Perak Port has contributed significantly to economic growth and had important roles in increasing the commercial sector in East Java and Eastern Indonesia. 
The supports are from 13 agencies in Tanjung Perak port area which include Tanjung Perak port main authority, Tanjung Perak Main Harbor, Navigation District class I in Surabaya, Tanjung Perak Harbor Police Station, Port Health Office class I in Surabaya, Surabaya Agricultural Quarantine Office, Immigration Office Class I in Tanjung Perak, Tanjung Perak Customs Tax Office, Tanjung Perak II Maritime Meteorological Station Surabaya, Fish Quarantine Center for Quality Control and Safety of Surabaya Fishery Products II, Tanjung Perak Sea and Coast Class II Safety Base, Air Police Directorate of East Java Regional Police and Pelindo III has committed to realize the vision of Tanjung Perak Port which is in action, a courageous, honesty, trustful and non-corruption area. All related institutions have tried to improve the management of change, governance, management of human resources, management systems, strengthening accountability, supervision, and public services.

Table 1. The supporting and inhibiting factors in implementing the policy are:

\begin{tabular}{|c|c|}
\hline Supporting Factors & Inhibiting Factors \\
\hline $\begin{array}{l}\text { 1. The facilities in } \\
\text { Tanjung Perak Port } \\
\text { are well managed } \\
\text { and it can be seen } \\
\text { from the continuity of } \\
\text { distribution. } \\
\text { 2. The efforts are made } \\
\text { to facilitate service } \\
\text { users in submitting } \\
\text { complaints, } \\
\text { suggestions, input or } \\
\text { criticism, namely } \\
\text { providing various } \\
\text { means of complaints } \\
\text { such as the } \\
\text { availability of a } \\
\text { suggestion box, call } \\
\text { center for complaint } \\
\text { information and } \\
\text { consultation in the } \\
\text { one-stop service } \\
\text { center building } \\
\text { (PPSA). In inplementing the } \\
\text { 3. In imple in } \\
\text { seaport policy in } \\
\text { Tanjung Perak Port } \\
\text { supported by the } \\
\text { organizational } \\
\text { structure of related } \\
\text { parties such as } \\
\text { Pelindo III Tanjung } \\
\text { Perak Surabaya, }\end{array}$ & $\begin{array}{l}\text { 1. The quality of } \\
\text { human resources in } \\
\text { Tanjung Perak can } \\
\text { affect the process } \\
\text { of the loading and } \\
\text { unloading cargo } \\
\text { and the documents } \\
\text { process because } \\
\text { these activities are } \\
\text { carried out using } \\
\text { tools and human } \\
\text { labor. } \\
\text { 2. It is a fact that the } \\
\text { bureaucracy is still } \\
\text { complicated to } \\
\text { handle export and } \\
\text { import documents. } \\
\text { Therefore, } \\
\text { business people in } \\
\text { Indonesia should } \\
\text { visit several places } \\
\text { that are far from the } \\
\text { port. Business } \\
\text { people are always } \\
\text { queuing in every } \\
\text { place for } \\
\text { completing their } \\
\text { documents. For this } \\
\text { reason, handling } \\
\text { export and import } \\
\text { documents are }\end{array}$ \\
\hline
\end{tabular}

\begin{tabular}{|c|c|}
\hline $\begin{array}{l}\text { Tanjung Perak } \\
\text { Syahbandar, KPLP } \\
\text { Tanjung Perak Port, } \\
\text { Directorate General } \\
\text { of } \\
\text { Transportation, and } \\
\text { Directorate Sea and } \\
\text { Coast Guard Unit. } \\
\text { Some of these } \\
\text { agencies carry out } \\
\text { cooperation and } \\
\text { coordination well in } \\
\text { order to provide } \\
\text { passenger safety } \\
\text { and security. }\end{array}$ & $\begin{array}{l}\text { inefficient in term of } \\
\text { time management. } \\
\text { 3. The visible } \\
\text { shortcoming of the } \\
\text { Port is the Waiting } \\
\text { Time which means } \\
\text { the ships enter the } \\
\text { port and they must } \\
\text { wait for the help of } \\
\text { scouts and tugs. } \\
\text { This is happened } \\
\text { because of the } \\
\text { speed of the scout } \\
\text { ship itself, the lack } \\
\text { of the pier, the } \\
\text { loading and } \\
\text { unloading speed or } \\
\text { Bert Time, as the } \\
\text { result, the ships } \\
\text { have to queue. }\end{array}$ \\
\hline
\end{tabular}

\section{CONCLUSION}

The study can be concluded that the management policy in Pelindo III Tanjung Perak Surabaya is implemented well. There are also some inhibiting factors to support the management policy, such as the quality of human resources, the complicated bureaucracy in processing the export import documents and the ships have to queue because of the visible shortcoming in the port.

\section{ACKNOWLEDGEMENT}

The authors greatly acknowledge the support from Hang Tuah University Surabaya Indonesia for providing the necessary resources to carry out this research work. The authors are also grateful to the anonymous reviewers and journal editorial board for their many insightful comments, which have significantly improved this article.

\section{REFERENCES}

Akib, H. (2010). IMPLEMENTASI KEBIJAKAN: Apa, Mengapa, dan Bagaimana HAEDAR AKIB. Jurnal Administrasi Publik, 1(1), 111.

Andhika, S. N. (2015). Kualitas Pelayanan Jasa Terminal Penumpang Gapura Surya Nusantara Pada PT. Pelindo III (Persero) Cabang Tanjung Perak Surabaya. Publika, $3(1)$. https://doi.org/10.1017/CBO9781107415 324.004

Chariri, A. (2009). Landasan Filsafat dan Metode Penelitian Kualitatif. Workshop Metodologi Penelitian Kuantitatif Dan Kualitatif, 1-27. 
Hasibuan, D. K. (2014). Implementasi Program Kesehatan dan Keselamatan Kerja (K3) Kepada Tenaga Kerja Bongkar Muat yang Berada di Koperasi Samudra Sejahtera (KOMURA) Pelabuhan Samarinda. EJournal IImu Pemerintahan, 1(6), 17421752.

Mandala, E., Setyadiharja, R., Jefri, J., Renaldi, R., \& Mulyani, N. (2016). Implementasi Kebijakan Penerbitan Surat Persetujuan Berlayar (SPB). Jurnal IImu Pemerintahan : Kajian Ilmu Pemerintahan Dan Politik Daerah, 1(2), 249. https://doi.org/10.24905/jip.v1i2.603

Rahmat, P. S. (2009). Penelitian Kualitatif.

RI, M. P. (2016).pm_146_tAHUN_2016.

Solichin, M. (2015). Implementasi Kebijakan Pendidikan Dan Peran Birokrasi. Jurnal Studi Islam Oktober, 6(2), 148-178. https://doi.org/1978-306X

Syahruddin. (2010). Evaluasi Implementasi Kebijakan Pengembangan Kawasan Industri. Jurnal IImu Administrasi Dan Organisasi, 17(1), 31-42.

Syarifuddin, M. F., Al Musadieq, M., \& Yulianto, E. (2016). Pentingnya Pelabuhan Tanjung Perak Bagi Perekonomian Jawa Timur(Studi pada PT . PELINDO III Tanjung Perak Surabaya ). Jurnal Administrasi Bisnis (JAB), 35(1), 172178. 